\title{
Design of Sprinkler for Agricultural Purpose
}

\author{
Bhavani Shankar $\mathbf{Y}^{1}$, Cariappa A B ${ }^{2}$ \\ ${ }^{1}$ UG - Mechanical Engineering, Vidya Vardhaka college of Engineering, Mysore, Karnataka. \\ ${ }^{2}$ UG - Mechanical Engineering, Vidya Vardhaka College of Engineering, Mysore, Karnataka.
}

\begin{abstract}
As agriculture is the backbone of India. It is Important to spread the manure and spray pesticides to crops in order to protect it, So that it avoids the crops to get rotten and infected from pathogenic organisms like fungi, bacterium , mycoplasma, parasites and insects. As our farmers are still using the same method of scattering the chemicals in a same old fashioned way that is, by carrying it on their back and using their hands which is harmful to their Skin and it is also time and energy consuming. So, we are aiming to simplify the method of spraying pesticides and spreading manure to the crops, by this it also reduces the labour cost for the farmers. As spraying of pesticides and spreading of Manure cannot be done simultaneously, hence by introducing a detachable setup, the farmer will just have to push the cart with easy operation. It is a multipurpose model that is efficient in operation.
\end{abstract}

Keywords - Pesticide Spraying Machine, Manure.

\section{INTRODUCTION:}

Agriculture is the primary source of livelihood for about $60 \%$ of the total population of India. Agriculture is the backbone of Indian and contributes 16 to 17\% for GDP. Crop yield is reduced by mainly due to attack of pests, diseases and weed. Chemical control is the popular method adopted for controlling most insects, weed and diseases. The chemicals are applied either by spraying or sprinkling on the crop with help of pump or dusting. Spraying is one of the most effective and efficient techniques for applying spray liquid to crops in order to protect it. The design is based on the trolley operated system by this we can reduce work and time consumption. As farmers are still using the same old method to spray pesticide, it might have a lot of side effects like skin disease and also eye irritations, it also have some serious health effects like cancer, asthma and allergies. So, with the help of this sprinkler farmers can easily spray pesticides and also spread manure with less labour cost as there is no need of more labours, and time consumption is less. This multifunction device will come in handy that can be put to use in different spraying stages of farming as per process requirement. So we have designed a pesticide spraying machine which will not only increase productivity but also will reduce the effort of the farmers. The machine will save the time of the farmer as well as efficiency in spraying. This model carries multi nozzle pesticides sprayer pump which will perform spraying at maximum rate in minimum time. Constant flow valves can be applied at nozzle to have uniform nozzle pressure e. Owing to concern towards protecting environment from pollution by excessive use of pesticide and to economies the spraying method suitable alternative should be identified. In India, diverse farm mechanization scenario in country due to varied size of the farm holdings and socio-economic disparities. Most of farmer in India are small and marginal land holder. The spraying operation done by sprayer which consumes more time and energy. Tractor operated sprayers are difficult for adaption by the farmer due to existing cropping patterns, available field size, field condition during the rainy season. To overcome these problem Pesticides sprayer is a good idea while it can be used easily on fields without any difficulties as tractors and other sources cannot be moved on fields during rainy season, this Pesticides machine can be used easily at any time.

\section{LITREATURE SURVEY:}

The Food And Agriculture Organization [FAO] has defined pesticide as: Any substance or mixture of substances intended for preventing, destroying, or controlling any pest, including Sectors of human or animal disease, unwanted species of plants or animals, causing harm. The term includes substances intended for use as a plant growth regulator, defoliant, desiccant, or agent for thinning fruit or preventing the premature fall of fruit. Also used as substances applied to crops either before or after harvest to protect the commodity from deterioration during storage and transport. The equipment is purposely design for the farmers having small farming land say 5-6 acre. It is suitable for spraying as well as weeding at minimum cost for the farmer so that farmer can afford it. The equipment will result more beneficial when it is subjected to moist soil for weeding purpose, due to moist soil the weed cutter can easily penetrate and dig out the soil and hence will easily accomplished the weeding process. Spraying of fertilizer is accomplished by the help of a storage tank in which pump is submerged to pump out the liquid by a multiple nozzle attached via a pipe. Since seeds and fertilizers are placed in a sowing box over wastage of the same is eliminated, thus it will reduce the cost in planting. 


\section{International Advanced Research Journal in Science, Engineering and Technology}

Vol. 8, Issue 6, June 2021

\section{DOI: $10.17148 /$ IARJSET.2021.8698}

Varikuti Vasantha Rao Sharanakumar Mathapati Dr. Basavaraj Amarapur," Multiple Power Supplied Fertilizer Sprayer ".

Shivaraj kumar Parameshwarmurthys paper on design and development of wheel and pedal operated sprayer - It is a portable device and no need of any fuel to operate, which is easy to move and sprays the pesticides by moving the wheel and also peddling the equipment.

P. V. Sawalakhe and Amit, Sontakke, (global journal of solar seeding machine), [Cited on research paper]- 2016 they investigated that there is a rapid development in all sector including the agricultural sector as well. So in order to meet the future food requirements, the farmers need to change their techniques to overcome the traditional method of farming. This Paper describes the various sowing methods implemented in agriculture for seed placements.

Kamlesh Kishor Rangari, Swapnil B. Bandane, Pravin Jaybhaye, Dr. S.K. Choudhary, Prof. R.D. (2015) "Design and fabrication of organic fertilizer and pesticides sprayers". International Journal for Scientific Research \& Development.

\section{METHODOLOGY:}

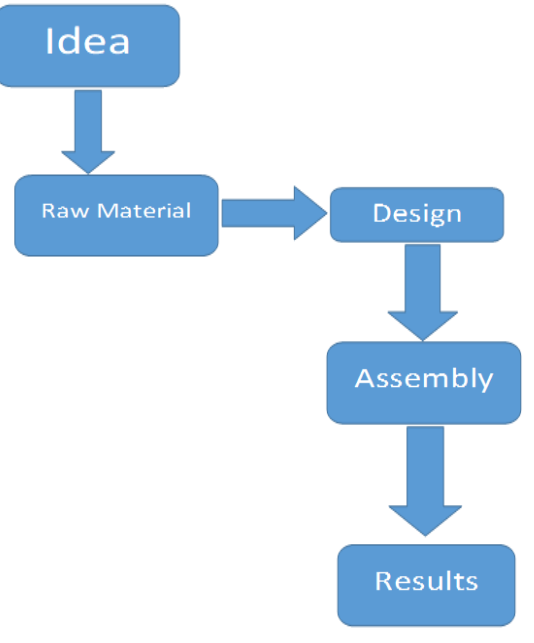

1. Idea: First we need to come up with a idea which will be useful in some or the other way as we came up with this idea because most of the farmers are still working in a same old way as we wanted to simplify the methods under pesticides spraying sector.

2. Raw Material: After we come up with an idea of modelling, we have to search for the suitable raw materials for the model. The main importance of choosing a suitable raw material is to reduce weight so that it can be moved easily on the fields.

3. Design and Assembly: Design is nothing but sketch of the model using software called solid works. Using this software we design the parts of the model like sprockets, main frame, wheels. Once we finish designing we will move on to assembly of the parts. After assembly fabrication work will be started.

4. Real time testing: Soon after the fabrication work we need to test it on fields as trial and error method so that if there any problem faced we can modify it with any other methods.

\section{DESIGN:}

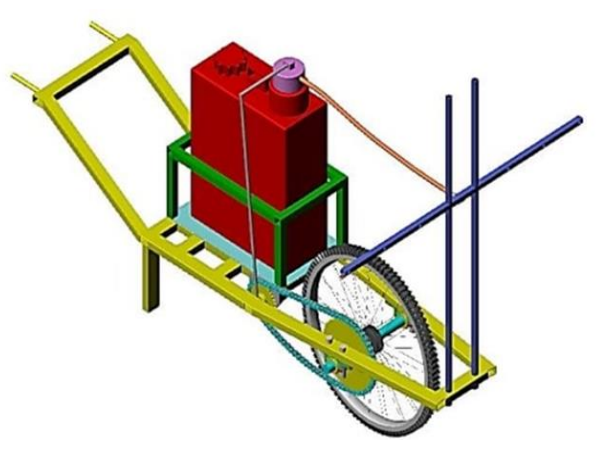

PESTICIDES SPRAYER 


\section{International Advanced Research Journal in Science, Engineering and Technology}

Vol. 8, Issue 6, June 2021

\section{DOI: $10.17148 /$ IARJSET.2021.8698}

The above figure can be used for spraying liquid pesticides that avoids farmers to use hand operated system to spray pesticides for the whole field.

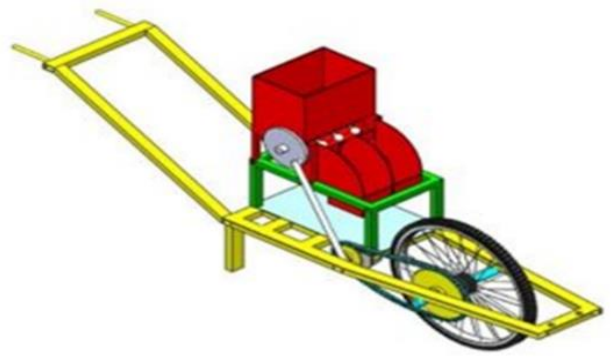

\section{MANURE SPREADER}

The above figure is used for manure spreader that helps farmers to spread manure easily with the help of this spreader.

\section{RESULT AND CONCLUSION:}

This design reduces the maintenance, human efforts, cost as well as manpower. As very less effort required at actual field for this Two in one and compact design makes it user efficient at comfortable level. Area sprayed per hour can be increased of by using this method. Comparison between the existing machineries and present machine shows that the tricycle operated machine can work very efficiently with respect to covering area, time and cost of spraying process. Also it seems economical. It is suitable for the spraying at minimum costs for the farmers so that they can afford it easily. Cost effective project which can be affordable by low and middle level farmers through Government subsidies. Initial investment and maintenance cost is very low Provides flexible way of spraying method for farmers without damaging the flowers and getting them hurt from thorns present in flowers stems. Project implementation eliminates the labour charges. It can be concluded that the present project work is no more exhaustive and it can be developed as future scope of project.

\section{REFERENCES:}

1. Prof. Basavraj R. Birajdar1, Prof. Mallikarjun B. Awate, Prof. Prasad N. Kulkarni and Prof. Aditya D. Dhobale. "Design and Fabrication of Fertilizer Spreading Machine", ISSN: 2321-9653, Volume 6 Issue 7, pp 238-245, July 2018.

2. Nitish Das, Namit Maske, Vinayak Khawas, Dr. S. K. Chaudhary and Er. R. D. Dhete, "Agricultural Fertilizers and Pesticides Sprayers - A Review”, International Journal for Innovative Research in Science \& Technology ISSN: 2349-6010, Volume 1 Issue 11, pp 45-47, April 2015.

3. Nitin Kumar Mishra, Shashwat Khare, Sumit Singh, and MithunDabur, "Multi-Purpose Agriculture Machine" International Journal of Advances in Science Engineering and Technology, ISSN: 2321-9009, Vol-5, Iss-1, Spl. Issue-2 pp 40-43, and Feb.2017.

4. Veeresha G, Abdul Raheem, Abdul Kadeer Ansari, Dinesh Yadav and Md. Mainudin Ansari, "Design and Fabrication of Multipurpose Agricultural Equipment", International Research Journal of Engineering and Technology, e-ISSN: 2395-0056, Volume: 05 Issue- 07, pp 912-914, July 2018.

5. Faijubhai Malek, Dipam Patel, Yash Padia, Mit Kundariya and Varun Jarsania, "Mechanically Operated Cart for Pesticide Sprayer for Agriculture", International Journal of Innovative Research in Science, Engineering and Technology ISSN: 2347- 6710, Volume 5, Issue 5, pp 6704-6711, May 2016.

6. S.V.Deshpande1, Damre Mayur, Diwanale Swapnil AGRICULTURAL RECIPROCATING MULTI SPRAYER. Assistant Professors: Department Of Mechanical Engineering, GSMCOE, Balewadi, Pune, (India)

7. D. Khorgade, Design And Development Of Multipurpose Pesticides Spraying Machine, 5Student, BE (Mechanical Engineering), Asst Prof. Mechanical Engineering Dept. Gurunanak Institute of Technology, Nagpur-441501, Maharashtra, India.

8. Dhineshbabu V.; Aswin K. A; Bharath Prithivi B.; Dhanush Kumar P.. "Design and Fabrication of Industry Based Hydraulic Manifold Using Additive Manufacturing". International Research Journal on Advanced Science Hub, 3, Special Issue ICIES-2021 4S, 2021, 34-41. doi: 10.47392/irjash.2021.107

9. Ravindra Parab; Pawan Pandey. "Design Smart Solar Inverter using e-waste with IOT control". International Research Journal on Advanced Science Hub, 3, 1, 2021, 5-12. doi: 10.47392/irjash.2021.002

10. Madhu raghava; Rajendra D. "Design and Fabrication of Dual Power Sprayer". International Research Journal on Advanced Science Hub, 2, 7, 2020, 15-23. doi: 10.47392/irjash.2020.58

11. Mr. Sumit D. Raut, Prof. Kamlesh R. Banarse, Prof. Roshan R. More Worked On Fabrication Of Pedal Operated Reciprocating Pesticide Sprayer For Agricultural And Drainage Line Use.

12. Ahmad Suhaizi Mat Su and Desa Ahmad, "Friction Coefficients of Selected Agricultural Soil and Agro-Products - A Review", in conference Mytribos Symposium 2, pp.19-21, 8 Oct 2017.

13. Shailesh Malonde, Shubham Kathwate, Pratik Kolhe, RoadneyJacob, Nishat Ingole and Rupesh D. Khorgade, "Design andDevelopment of Multipurpose Pesticides Spraying Machine”,International Journal of Advanced Engineering and GlobalTechnology ISSN No: 2309-4893 Volume 4, Issue-03, pp 1945-1953, May 2016.

14. Ahmad Suhaizi Mat Su and Desa Ahmad, "Friction Coefficients ofSelected Agricultural Soil and Agro-Products - A Review", inconference Mytribos Symposium 2, pp.19-21, 8 Oct 2017

15. Prof.SwapnilL.Kolhe,NileshB.Gajbhiye,VivekB.Deshmukh, "Eco-friendly Mechanically Operated Multipurpose Spray Pump", "International Journal of Research in Advent Technology",E-ISSN:2321-9637, Volume 02, Issue 02,Feb-2014.

16. DhirajN.Kumbhare,VishalSingh,Waghmare,AltafAnsari,VikasTiwari,Prof.R.D..Gorle, "Fabrication of Automatic Pesticides Spraying Machine", "InternationalResearch Jornal of Engineering and Technolagy",ISSN:2395-0056,Volume 03,Issue-04,Apr-2016.

17. Sarvesh Kulkarni, Kara Hasurkar, Ramdas Kumbhar, Amol Gonde, Raut A.S. A research paper on "Review of Solar Powered Pesticide Sprayer".

18. Laukik P. Raut, SmitB. Jaiswal, Nitin Y. Mohite A research paper on "Design, development and fabrication of agricultural sprayer with weede 